\title{
Networks in Public Administration Scholarship: Understanding Where We Are and Where We Need to Go
}

\author{
Kimberley R. Isett*, Ines A. Mergel', Kelly LeRoux", Pamela A. Mischen', \\ R. Karl Rethemeyer** \\ "Columbia University; 'Syracuse University; ${ }^{*}$ University of Illinois-Chicago; \\ ${ }^{\S}$ Binghamton University; ${ }^{* *}$ University at Albany-SUNY
}

\section{ABSTRACT}

\begin{abstract}
This article examines the road that network scholarship has followed in Public Administration. We look at the historical drivers of the use of networks in practice and scholarship in the field and discuss how that has shaped the current literature. The body of the article focuses on the current challenges that network scholars face in the discipline, specifically basic theoretical issues, knowledge about formal networks, knowledge about informal networks, and methodological issues. We close the article with a look to the future and some suggestions for the future of network scholarship in Public Administration.
\end{abstract}

\section{INTRODUCTION}

In recent years, there have been several "retrospective" articles about network scholarship in other disciplines that facilitate academic naval gazing at what has been accomplished, what still needs to be done, and the connections between disparate strains of the literature (e.g., Brass et al. 2004; Provan, Fish, and Sydow 2007). However, each of the different disciplines involved in network studies has its own foci and emphases that are important to their brand of work. As such, we take this opportunity to provide a commentary on the development of network studies in Public Administration and suggest the main challenges that we face as a community.

The focus on networks in Public Administration has grown rapidly in the past decade and a half. The use of networks by practitioners has exploded as well as the number of scholars of public organizations who study them or who find the conceptualization useful. At the last National Public Management Research Conference held in Tucson, AZ, organizers noted the upsurge of submissions dealing with this topic. So we ask: How did we get from little network scholarship 20 years ago to such a preoccupation with the topic today?

This work is the product of group discussion from the Minnowbrook III New Scholars workshop held in September 2008. The authors gratefully acknowledge the input of the other group members who chose not to be included on the work of this article, Charlie Schweik, and Maja Holmes. We would also like to acknowledge the participants of the breakout discussion at the Minnowbrook conference and their stimulating discussion to refine some of our initial ideas. Address correspondence to the lead author at ki2129@columbia.edu. 
The answer is not entirely straightforward. We can identify three main streams of research on networks that appear in the current literature. The oldest effort focuses on policy networks. Policy networks are a set of public agencies, legislative offices, and private sector organizations (including interests groups, corporations, nonprofits, etc.) that have an interest in public decisions within a particular area of policy because they are interdependent and thus have a "shared fate" (Laumann and Knoke 1987). The original conceptualization of policy networks concerned decision making about public resource allocation.

Networks focusing on the provision and production of collaborative goods and services are the second important stream of literature. Collaborative networks are collections of government agencies, nonprofits, and for-profits that work together to provide a public good, service, or "value" when a single public agency is unable to create the good or service on its own and/or the private sector is unable or unwilling to provide the goods or services in the desired quantities (cf. Agranoff and McGuire 2001, 2003; Mandell 2001; Nelson 2001; O'Toole 1997a). Collaborative networks carry out activities on behalf of the public. They may be formal and orchestrated by a public manager or they may be emergent, self-organizing, and ad hoc, with many variants in between.

The third stream of literature is on governance networks. Governance networks are entities that fuse collaborative public goods and service provision with collective policymaking - for instance, business improvement districts or some environmental mitigation efforts (Bogason and Musso 2006; Klijn and Koppenjan 2000; Klijn and Skelcher 2007; Rhodes 1997; Sørensen and Torfing 2005). These networks focus on the coordination of organizations toward a common goal rather than the policies or products that the networks actually produce.

As Berry et al. (2004) note, each of these programs of research have their roots in other disciplines, though public administration scholars have written on all three (and sometimes have confused all three - see Börzel 1998). However, until the recent work on governance, scholars pursued programs of research that fell broadly into either the policy or collaborative literature. ${ }^{1}$

\section{Historical Roots}

As Kettl (1996, 2000), Salamon (1981, 2002), and others have pointed out, government no longer directly creates public "value" (to use Moore's [1995] phrase). Instead, nearly 19 of every 20 dollars of federal spending are funneled through third parties (Salamon 2002, 4). This rather startling movement toward third-party public goods production occurred over 30 or 40 years as a set of social and economic changes took hold in the United States and across the world. Though some movement away from bureaucratic service provision began earlier, a key component in this transformation was the reemergence of conservative parties in the United States, the United Kingdom, and to a lesser extent in Europe. The Reagan and Thatcher Administrations in particular were swept into power by anti-tax/small government movements that reinvigorated debate on the proper division of labor between the public and private sectors. Reagan and Thatcher both began rapid programs of privatization and marketization of the public sector.

1 In the conclusion to their influential volume on "managing complex networks," Kickert, Klijn, and Koppenjan (1997:181 3) explicitly address the division between those who view networks as solely instrumental and those who see them as integrative of decision and implementation. 
In response to the call for the "third-party governance" of Reagan and Thatcher, the "New Public Management" (NPM) emerged with its market-based prescriptions providing rationales and templates for the marketization of public goods and services and "privatized" (i.e., made voluntary) regulation. However, the NPM program in theory and practice ran up against several realities: many services cannot be sufficiently homogenized so that contracting out is possible, centralized regulation marched on as citizens continued to demand more governance but less government (Osborne and Gaebler 1992), and the problem of small numbers bargaining and transaction-specific capital (Williamson 1981) attenuated the expected efficiency benefits of marketization. Moreover, there were classes of problems - what Rittel and Webber (1973) had earlier termed "wicked problems"- to which markets seemed poorly suited for classic contracting. Wicked problems require experts from disparate fields to cooperatively construct a reasonable and feasible way to address the complexities inherent in the problem at hand. No one organization or individual possesses the tools needed to adequately address problems that do not respect political, disciplinary, and industrial boundaries (Kettl 2006). In these classes of problems - which are becoming increasingly common-NPM's prescriptions were insufficient.

Networks, then, are in part a response to the insufficiencies of NPM in the face of complexity, mission expansion, government de-legitimization, and knowledge creation needs that are posed by wicked problems. Networks provide flexible structures that are inclusive, information rich, and outside the scope of direct bureaucratic control. These structures allow public agencies to manage public problems by leveraging expertise held outside its scope of authority. Thus as O'Toole (1997b), echoing earlier work on alternative forms of governance by Ostrom (1990) and other "sociologists and public choice specialists", pointed out, networks are an alternative when markets and bureaucracies fail. As several commentators have noted (cf. McGuire 2006; O'Toole and Meier 2004), much of the research on collaboration has been optimistic about the quality and nature of resulting goods and services. However, another strain in the literature has been more skeptical of networks on performance and accountability grounds (e.g., Freeman 1965; Heclo 1977; Laumann and Knoke 1987; McCool 1989, 1990).

\section{Preaching What Is Already in Practice}

There is little doubt that practitioners have sprinted ahead of the academic research with regard to networks. Network forms of organization emerged and spread during the 1970s but seem to have flowered during the 1990s when the Clinton Administration embraced government reinvention in the face of renewed political resistance to expanded government. The primary program of academic research in public administration, however, can probably be dated to the late 1990s - though prescient scholars such as Salamon (1981) began to note the movement toward networks in the Reagan years. The emergence of network studies in public administration research, then, was playing catch up to the structures already put in place- from complex contracting structures, to networks created to build specialized defense hardware, to emergent social service networks rowing the deinstitutionalization movement, and to regional multisector schemes for environmental management. The degree to which these innovations were self-consciously constructed as networks is open to debate. Nonetheless, scholars are increasingly discovering public goods and service provision structures that meet current definitions of networks. 
Network studies, then, are a response to a new administrative reality driven by social, political, and economic forces. The studies that have emerged over the last decade or so have their roots in earlier programs of research founded in political science, sociology, and the policy sciences - particularly in the programs of research on interorganizational networks (Galaskiewicz 1985; Rogers and Whetten 1982) and the concept of boundary spanning (Adams 1976; Aldrich and Herker 1977), as well as the lived experiences of master practitioners who drew academic attention to their innovations. Despite the rapid growth of the networks literature in Public Administration, the field is still in its early stages. Scholars remain faced with fundamental questions and challenges that make network studies a variegated undertaking where a variety of phenomena are described in multiple ways. We now turn to a discussion of these fundamental questions.

\section{CHALLENGES FACING PUBIC ADMINISTRATION NETWORK SCHOLARSHIP}

\section{General Theoretical Issues}

This section covers three fundamental issues in the current Public Administration network literature: definition of networks (and how the term "network" is used), unit of analysis, and terminology. These issues are all interrelated, but each pose important conceptual concerns that merit separate attention.

\section{Definition}

Perhaps the most fundamental issue that faces network scholars today is the diverse definitions that are used for the term. The word "network" is used loosely throughout the literature and can refer to many different things, including (but not limited to) a gathering of actors with (a) different levels of coupling who may or may not be cognizant of their "corporateness" which are (b) operationalized at various levels of analysis (individuals, organizations, etc.) using (c) multiple conceptual approaches and agendas (metaphor/ organizing concept, method, utilitarianist) and (d) an array of static versus dynamic and agency-based notions. Although all these forms may be networks of some sort, there is a lack of clarity with which scholars in Public Administration use the term. Thus, we have an amorphous set of studies that do not necessarily belong to a distinct intellectual tradition or even a clear understanding of what studies hang together as subsets of a broader tradition.

We suggest that there are three general ways in which "networks" are used in the public administration literature ${ }^{2}$. One way the term is generally used is as a metaphor or an organizing concept. Here we see studies that invoke a network conceptualization of a social phenomenon that may not necessarily have a structure or corporate entity that defines the network, but the network metaphor provides a useful and powerful way to understand what is going on in the social context under examination. This use raises the important and critical issue of whether the actors in an attributed network (meaning a group where the network paradigm is applied) must acknowledge and accept that they operate in a network for it to actually be a network. This approach is probably best typified by the research program of networks by Meier and O'Toole (e.g., Meier and O'Toole 2003; O'Toole and Meier 2004) and much of the European and Asian networks literature. 
A second way the term is used is to refer to the methods and methodological paradigm that surrounds networks, social network analysis. In this use, structure and the measurement of structural dynamics is the focus. Although most network scholars use some sort of network methodology in their studies, the "method" approach is really focused on the development of tools, the refinement of measures, and the appropriateness of usage. Here, network structure is paramount to the meaning of those structures or the practical uses of those applications. Many of the articles found in the journal Social Networks would fall into this category, as well at the scholarship of the "Dutch School" (e.g., Snijders and Bosker 2000) who are pioneering many of the stochastic techniques that are emerging currently.

The third way that networks are used in the Public Administration literature is mainly utilitarian - as an approach or as a tool to understand public service provision. Here, networks are used to get something done, such as the service delivery networks studied by the "Provan school" of scholars (Huang and Provan 2007; Isett and Provan 2005; Provan, Milward, and Isett 2002) and local collaborative governance as studied by the "Agranoff school" (Agranoff 2007; Agranoff and McGuire 2001, 2003) (and as extended by Feiock and his colleagues, particularly with their use of social network analysis [see, e.g., Feiock 2004, 2007; Feiock and Scholz 2009]). From these efforts, we have begun to understand how networks may deliver and create services in a coordinated way. However, most of these studies tend to focus on formal networks - those networks officially set up by some convening body where membership may either be coerced or have some compelling normative or resource incentives to participate - thereby leaving important classes of networks, emergent and informal, underexplored.

All these perspectives are meaningful and provide one part of the networks landscape. However, the implications of networks differ depending on how they are conceptualized and studied. Importantly, scholars to date have not self-consciously placed their studies in a subsection of the literature, so there are few opportunities to determine whether findings are commensurate with one another and thus cumulative in their effect on the literature. It is curious that much of the older work was completed in the utilitarian mode, whereas much of the newer work seems to be metaphorical, with little original work in Public Administration being done on methodology.

\section{Unit of Analysis}

An issue in the networks literature that has yet to be resolved is the appropriate unit of analysis for a network study. Fundamentally, a network can be defined as a group of goal-oriented interdependent but autonomous actors that come together to produce a collective output (tangible or intangible) that no one actor could produce on its own (Alter and Hage 1993; Isett and Provan 2005; Koppenjan and Klijn 2004). Interorganizational arrangements within this rubric are often nonhierarchical and participation is noncoercive, but that is not always the case. Network analysts often assume that the relationships embedded within a network are predicated on all the other relationships in that network. That is, new relationships are dependent upon the structure of relationships that already exist in the network and the degree of reachability and redundancy that is desired within the network (Burt 1992; Granovetter 1985; Isett and Ellis 2007). The debate about unit of analysis comes into play with regard to whether "whole networks" must be studied or if there is leverage in studying component substructures. The answer is that both perspectives have merit. However, there has been a lack of systematic work on networks as a whole, 
hindering our ability to understand just how the whole functions separately from its parts (Provan, Fish, and Sydow 2007). The key to the study of network substructures is to be conceptually and analytically clear as to whether the unit of analysis is actually a network substructure or whether the unit of analysis is just a free standing dyad, cluster, or the like. Although intellectually we can expect that these two things (a freestanding cluster or an embedded network substructure) are related, we also need to understand what it is about networks that make dyads, for example, different when they are in networks and when they are not. The assumption here is that a network is more than just a collection of atomistic relationships. This assumption is not trivial as it conditions a range of dynamics among members, such as the effect of transactions costs and reputation (Isett and Provan 2005).

\section{Terminology}

Throughout the Public Administration literature, we see references to networks with regard to coordination, collaboration, and cooperation. Although networks can serve these functions, these functions can also exist outside of networks. However, all these terms are used interchangeably. This often leads the reader to assume that networks are coordinative mechanisms or are cooperative mechanisms. However, this may simply not be the case.

There is a basic agreement among scholars that networks serve some collective action function. But the form this function takes may be varied and widely arrayed on a plane of options. So, although networks may serve to facilitate cooperation or coordination, they do not necessarily have to do so. They could simply exist to facilitate social exchange or to decrease transactions costs for a defined membership group without coordinating at all. Moreover, there is nothing to stop interested actors from forming networks for the express purpose of frustrating political or collaborative activities. Again, we call for increased clarity in future network studies regarding the degree to which a given network exists to facilitate coordination, cooperation, or collaboration and to think carefully about non-networked instances of cooperative behavior. Conversely, we call for more studies that examine networks that are not explicitly built to foster the three predominant collective action functions. Such studies could better establish the range of functions networks fulfill and serve as a basis of comparison for the evaluation of cooperative networks.

\section{Disconnect between Formal and Informal Network Research}

In this section, we highlight the existing work on both formal and informal networks. Although our discussion focuses on formal networks, this is merely an artifact of the existing work on networks in the field. In fact, we believe there to be considerable merit in further developing the set of studies that look at less formally created networks, as well as informal relationships within formal networks. Formal and informal networks differ primarily by the explicitness of their origins. Formal networks are consciously created with some sort of binding agreement for participation, whereas informal networks are more organically derived - an outgrowth of organizational contingencies that multiple actors come together to address.

\section{Formal Networks}

Formal networks are multiactor arrangements explicitly constituted by public managers to produce and deliver public services. Explicit constitution could take a number of forms 
including contracts, enabling legislation, memoranda of understanding, joint agreements, etc. ${ }^{3}$ Formal networks now serve as the preferred service delivery method for many forms of health and human services provision including public mental health (Provan and Milward 1995), child welfare (Romzek and Johnston 1999), adult basic education (Rethemeyer and Hatmaker 2008), and housing/homeless services (Hoch 2000). Local governments also rely on formal networks for managing economic development (Agranoff and McGuire 2003), public safety (Andrew 2009), the environment (Lubell et al. 2002), and a host of other municipal services such as fire protection, parks and recreation, sewerage, and solid waste management (Shrestha and Feiock 2004).

Service delivery networks are typically made formal by contractual relationships between each network actor and a convening organization, the Network Administrative Organization (Provan and Kenis 2008; Provan and Milward 2001). Contracts serve to legally bind network actors together and specify the roles and responsibilities of participants. Although many formal networks in public administration are bound by contractual relationships, contracts are not the only tool for formalizing a network. Mutual aid pacts and memoranda of understanding also create formal networks where actors share a set of collective goals, have clearly defined roles, and display sustained commitment to these roles over time, even in the absence of legal obligations to fulfill network responsibilities.

For the past 15 years, the study of formal networks has been a central focus of public management research. During this time, empirical network studies have produced important insights for the practice of managing complex, multiorganizational arrangements. This research has been instructive in many ways: it has revealed the power structures that contribute to network effectiveness (Milward and Provan 1998) and how network participants overcome unexpected obstacles in mitigating public emergencies (Moynihan 2005); it has highlighted the skills required for successful network management (Agranoff and McGuire 2003; Koppenjan and Klijn 2004) and generated criteria for assessing network performance (Provan and Milward 2001), and it has explored how public managers' expectations and interactions with network contractors impact performance (Romzek and Johnston 2002).

Despite the intellectual progress the field has made in the study of networks, there are still many aspects of network management and performance that are not well understood. We face significant limitations in our knowledge of how networks perform over time (see the article by Moynihan et al. [2010] in this issue for an outline of the challenges facing measurement of network performance). Although there is some emerging work that examines the factors that promote network stability over time (Isett and Provan 2005) and the characteristics of public goods and services that shape the evolution of network participants' interactions (Andrew 2009), the field stands to benefit substantially from additional time-series investigations of formal networks. Such research would be especially useful if it were undertaken with the goal of identifying factors that contribute to successful network outcomes over time.

Further, scholars still confront methodological dilemmas in examining formal networks, particularly with regard to network boundary specification. Although network boundaries are often delineated for the purposes of empirical analysis, discovering the

3 This is not to say that the presence of formalized relationships is a sufficient condition for a network. As argued by many network scholars, a network is more than a series of dyadic relationships; there is a collective action component to them (Isett and Provan 2005). 
limits of networks in reality can be quite difficult. For example, many government contractors who produce and deliver services through a network rely themselves on an extensive network of subcontractors to whom they delegate authority and some degree of discretion in service implementation. In addition to subcontractors, network participants may make referrals or enter into partnerships with community or voluntary organizations that are not part of the formal network but are essential to network outcomes nevertheless. These common scenarios give rise to fundamental questions about where the boundaries of networks should be drawn, further blurs the boundaries of the "public," and diffuses accountability (Romzek 2008).

Another challenge in network research lies in arriving at conclusions that can be generalized. Networks are embedded in a specific policy context, and the behavior of network actors is defined by that context (Heikkila and Isett 2004). Therefore, much of what we know about managing networks from studies of mental health providers has questionable applicability to other types of networks. Formal networks arise from diverse institutional forms that subsist on diverse funding streams that carry differing regulations and rules for implementation. Networks are thus shaped and constrained by institutional rules as well as regulatory procedures and norms that are specific to the policy arena.

The decision to rely on networks as a service delivery method also creates a new set of political dynamics that network administrators must manage. Bringing multiple organizations into the service delivery process creates new types of interest group pressures, strengthens providers' lobbying power, and may even lead to provider collusion (Rethemeyer and Hatmaker 2008). Whether motivated by resource dependence, political change, or something else, network participants grow to have an increasingly large stake in policy outcomes (Hatmaker and Rethemeyer 2008). For all these reasons, network studies must account for the ways the policy context influences network outcomes.

Formal networks may be somewhat easy to manage because they are fairly stable. Their relatively closed structure leads to greater levels of trust among participants. Trust reduces transaction costs for both network managers and network participants. Informal relationships among network actors often strengthen formal network ties and may give rise to other types of cooperation. For example Thurmaier and Wood (2002) found that social networks among city managers and municipal department heads were the underlying force creating and sustaining the use of interlocal contract networks among municipalities in the Kansas City metro area. They credit the formation of these contractual service networks to high levels of trust and norms of reciprocity, which in turn reinforce the contractual agreements.

Although the notion that trust enhances network effectiveness is a generally accepted principle, there are again important variations in policy contexts that shape actors' commitment to network goals and their incentives to participate. Nonprofit organizations comprising a contract network of child welfare providers have a financial incentive to work together to achieve network goals. Fire chiefs from multiple cities in a metro area may trust each other just as much as the child welfare directors. However, without the same financial incentives as child welfare networks, fire chiefs may be less likely to display high levels of commitment to the goals of the emergency management network of which they are a part. This is because each emergency management network participants' primary obligations are to their own city, and therefore collective network goals can easily become displaced by an individual participant's own organizational priorities (see Chisholm 
1998). This is one reason networks might perform poorly. Current network research does not speak to the problem of "free riders" nor has it provided us with a set of heuristics about how to elicit participation from less-than-active participants or the shape and limits of trust in networks.

\section{Informal Networks}

From task forces, to coalitions, to $a d$ hoc committees, public and nonprofit organizations participate in a wide range of interorganizational networks that do not bind its members together through formal means. Despite the preponderance of these informal networks, the gap between research and practice is wider for informal networks than formal networks. There is no distinct body of literature on informal networks. Consequently, there has been very little advancement of our understanding of this pervasive mechanism of governance.

In contrast to formal networks, which are typically designed, informal networks tend to be emergent structures used for information sharing, capacity building, problem solving, and service delivery (Agranoff 2007; Provan and Milward 2001). Although some informal networks emerge for the single purpose of information sharing, all networks must engage in some degree of information sharing to accomplish their stated purposes. Interagency information sharing is viewed as a way to reinforce valued relationships (Dawes 1996), is considered reliable because of shared history (Powell 1990), and may be more consequential than information sharing that happens outside networks. Therefore, it is important to understand the role that informal networks play in the public sphere because they have a significant impact on what and with whom information is shared.

Informal networks are important tools for problem solving, capacity building, and service delivery as well. Describing the efforts of six watershed management programs engaged in collaborative problem solving, Imperial $(2005,296)$ notes that "collaborative activities such as work groups, task forces, advisory committees, and other formal and informal staff interactions were frequent occurrences. These interactive processes are important because they help network members find ways to work together, generate new ideas, share knowledge, solve problems, build relationships, and develop trust." When service delivery is achieved in an informal network, it tends to be a function of service coordination or what Agranoff $(2007,10)$ calls "outreach" networks in which network members "come together to exchange information and technologies, sequence programming, exchange resource opportunities, pool client contacts, and enhance access opportunities that lead to new programming avenues."

What many informal networks have in common is their tendency to become formalized over time (Abram et al. 2005; Imperial 2005). This transition from informal to formal networks has been noted outside of public administration as well (MacKenzie 2008; Minoglou 2002). Whether this is the dominant tendency for informal networks to formalize over time or whether this process is what attracts the notice of researchers is unknown. What most authors agree on is that formalization is a good thing in that it increases the capacity of the network and moves it beyond personal relationships (Imperial 2005) and increases accountability (Thacher 2004). Because formal networks are more likely to garner and share financial resources, participation in informal networks may be an important step for securing grants and contracts for organizations.

Because much of the research on informal networks has been approached through the lenses of cooperation, coordination, and/or collaboration rather than from a network perspective, many critical questions have not been asked. Fortunately, there is a long history of 
studying informal networks in the field of sociology (Marsden 1990; Wellman 1983). Many of the lessons learned and methods developed in this sociological subfield have been applied to the study of informal networks occurring within organizations. For instance, drawing upon an intraorganizational study exploring interpersonal trust conducted by Ferrin, Dirks, and Shaw (2006), Lambright, Mischen, and Laramee (2010) show that trust among public and nonprofit organizations is a function of personal (propensity to trust), dyadic (perceived trustworthiness of another), and third-party (trust transferability) influences. Similar future studies should investigate the role of power, the emergence of leaders, and the effects that trust, power, and leadership have on information sharing and the willingness to collaborate in the future.

Understanding relational dynamics is one step toward understanding the effectiveness of informal networks. Although strength of relationships is one way to measure effectiveness at the level of the network itself (Provan and Milward 2001), in emergent informal networks, these relationships ultimately have an impact on the network's overall structure (Monge and Contractor 2003), and this dynamic has yet to be explored. It will also be important to consider whether the structure that works best for a particular network is a function of the purpose of the network (e.g., information sharing, capacity building, problem solving, and service delivery). By studying the structure of optimally performing emergent networks, we may gain some insights into how best to design more formal networks.

Importantly, the lack of formal structure in some networks has critical implications for governance. Although one of the potential benefits of networks is that they allow for multiple stakeholders and perspectives to participate in the policy and implementation process, this is no guarantee that they will be representative or that certain voices or perspectives will be included. In designing formal networks, diversity of participation can be a requirement. Informal (socially based) networks, on the other hand, tend to exhibit high levels of homophily (Monge and Contractor 2003). If informal networks emerge from existing social ties, the evolution from informal to formal network may institutionalize discriminatory inclusion/exclusion criteria. More research into the evolution of networks from social networks, to informal interorganizational networks, to formal networks, and in some cases back to informal networks (Mulroy and Shay 1998) is needed to fully understand the role they play in governance.

\section{Methodological Issues}

\section{Sampling of Public Sector Networks}

As the unit of analysis in most network research is, per definition, the complete network, collecting network data is a lengthy process usually requiring several waves of surveys or application of snowballing techniques to identify all relevant actors. It is therefore usually easier to access formal networks instead of informal networks, where respondents might be more reluctant to reveal their perceptions of their connections. Nonetheless, identifying a network and understanding who the relevant actors are poses a challenge for network researchers. Specifying the boundaries around a network may induce bias through faulty recall of actors, omissions on the part of the researcher, or artificial boundaries that can misrepresent the actual network. If researchers let actors define their network themselves, recall issues that are mostly unintended (caused by impaired self-perception of individual importance or unintended forgetfulness) might emerge (Bernard, Killworth, and Sailer 1982). Researcher-imposed boundaries, however, usually lack the insights that insiders 
gain regarding the "true" membership of a network but may have the advantage of being theory driven. In either case, this poses important accuracy issues for the data.

To combat these sampling issues, new sampling and data collection methods are currently being developed in computer science and physics. These new methods might help to overcome the flaws in the existing approaches, but they also stretch the computational and analytic capacities of our existing models and analysis methods. One example of innovative sampling techniques is Barabasi's network analysis of cell phone records with multimillion data points (González, Hidalgo, and Barabási 2008). This data set consists of recorded interactions between cell phones from which the researcher can deduce the network structure. The data in these studies are not derived from individual perceptions and thus avoids recall issues. Further, the use of online data collection tools or data mining techniques may make it easier to capture network data previously impossible to obtain (e.g., large friendship networks on social networking sites such as Facebook). However, these advances create both opportunities and challenges since they generate data sets of unknown dimensions and of a size that can be overwhelming.

\section{Generalizability of Single-Case Studies in Network Research and Lack of Data}

One characteristic of the public sector is the division of government authority into natural boundaries: networks can be found within and across the federal, state, and local levels. The permutations of agencies and levels within substantive policy arenas make the public sector a unique research setting. Therefore, we often cannot generalize from single network case studies in one specific sector, agency, or state to other contexts in the public sector. Instead, we need to be more attentive to the specificity of the processes and dynamics in those substantive areas and be clear about what aspects transfer to new contexts. Unfortunately, at this time, little work has been completed that is comparative in nature, leaving the field with small pots of useful information rather than a universal theory of networks.

We do note, however, an exciting new paradigm toward more systematic data sharing and information dissemination developed in different research communities and funding agencies. The journal Nature, for instance, has called for more transparency through the publication of data sets and analysis steps together with final articles (Helly 1998). Likewise, the Journal of Peace Research and the Journal of Conflict Resolution are asking authors of quantitative empirical articles to make their data-along with computer programs, recodes, codebooks and exploratory files - available together with their article submission. Steps such as these would begin to allow our field to build a broader understanding of network (and other) phenomena without the expense of extensive data collection by making existing datasets more readily available.

In some cases, funding agencies require grantees to give other researchers access to collected data sets to reduce redundant data collection efforts and to save resources for newer projects. As a contractual requirement, funding organizations regard collected data sets as a public good for the research community. We have noticed that even though contractual requirements are in place, access to federally funded data are still limited and the rules are not enforced. With the exception of the Interuniversity Consortium for Political and Social Research (ICPSR) data library, social science data still remains predominantly "proprietary."

\section{Changes over Time and Dynamic Network Methods}

Current network studies in Public Administration are mainly focusing on static networks, capturing interaction at one moment in time and not taking into account changes that might 
occur in the social structure over time. We need to move toward dynamic network studies to understand the evolution of networks (see, e.g., Burk, Steglich, and Snijders 2007). So far there are only a few studies out of the Dutch school that are widely accepted in the research community as model studies for dynamic network research. Examples ripe for dynamic modeling in the public sector include: the network effects of public opinion making and deliberation processes over time; impacts of external events on networks (e.g., crisis situations such as Hurricane Katrina and its effect on the resilience network of a community) and social and human capital programs and their impact on existing social networks over time. In this context, we also see a need for within-network and between network studies, which would allow us to compare network structure and changes over time. Another potential application of evolutionary or dynamic models are evaluations of "before and after" impact analysis. So far it is problematic to capture the impact of an event such as an innovation or an intervention as we often do not have access to a comparable data set of the time before the network was created or the time after the event.

\section{THE FUTURE OF PUBLIC ADMINISTRATION NETWORK RESEARCH}

The research program on networks within our discipline is gaining momentum. At this juncture, it is important to "take stock" of where we have been and determine future directions that might be useful for the field. Throughout this article, we have outlined the major issues existing in the literature and discussed the challenges that still face us. Although we attempted to be as comprehensive as possible in our treatment of networks in the Public Administration literature, we of course, could not address every relevant topic of concern to our field. One such issue is the role of the State with regard to networks. Although this is an extremely relevant issue, we have decided that this issue was too broad and merited more attention than we could afford in this critique. Instead, we invite readers to look at the January 2010 special issue of JPART on "The state of agents" (Milward, Heinrich, and Frederickson, eds.) for a thorough treatment of this issue.

In conclusion, we offer four areas of concern, in addition to those already discussed earlier, that ought to be considered as the field moves forward. First, other disciplines are farther along in the study of networks (e.g., management, sociology, statistical physics) than Public Administration. Our field needs to be more cognizant of the network literatures in other disciplines and to employ this research to advance our own understanding of network issues in public sector contexts. One approach to creating a general theory of networks would be to think of the term "network" as a universal algorithm, rather than as a metaphor or specific functional form. This would avoid the "too much loose analogizing" (Beinhocker 2007, 12) that our field is experiencing at the moment with disparate uses of the term.

Second, Public Administration scholars need to foster closer ties with technical disciplines that are developing new methods and measures, such as computer science and statistical physics. The toolsets that emerge from technical fields are not always appropriate to study of the public sector. Fostering ties would aid in the development of more appropriate tools for the phenomena we study. Conversely, Public Administration network scholars also need to take the time to understand the technical aspects of the software and analytic tools they use, including the difference between social network measures and the visual representation of networks. Although structural analysis of networks is not 
the only way to study networks, structure does matter and is a critical element to understanding this increasingly ubiquitous form of organization. Enhanced understanding of analytic approaches will aid in the appropriate use of existing tools and measures as well as facilitate the development of theoretical linkages between public administration concepts and social network measures.

Third, the field needs to complete metastudies of network cases. Understanding what you understand is an important step in any young field of inquiry. Although traditional meta-analyses are not statistically possible within this field as of yet, it is still important to systematically evaluate the existing literature to describe the consistent findings that do exist and areas that seem to clash with one another. Currently, metastudies must be qualitative in nature but can later be quantitatively verified as the number of cases grows and as statistical methods are created to handle meta-analyses of dependent data sets.

Finally, Public Administration scholars need to become more engaged with practitioners. Engaged scholarship ought to address the real problems that practitioners face, rather than questions driven solely by theoretical interests. Theory strongly grounded in the experience of practitioners equals relevance - something that many in our field would like to achieve. Strong practitioner-researcher linkages will likely result in practitioners posing thorny issues that academics have not thought of, opening a whole new universe of intellectually interesting questions to our scholarly community.

\section{REFERENCES}

Abram, Faye Y., Heather A. Mahaney, Donald M. Linhorst, Sr.Jackie Toben, and Marie Flowers. 2005. Interorganizational collaboratives for children of prisoners: One that succeeds, another that struggled. Journal of Community Practice 13:31 47.

Adams, J. Stacy. 1976. The structure and dynamics of behavior in organizational boundary roles. In Handbook of industrial and organizational psychology, ed. M. D. Dunnette, 1175 99. Chicago, IL: Rand McNally.

Agranoff, Robert. 2007. Managing within networks: Adding value to public organizations. Washington, DC: Georgetown Univ. Press.

Agranoff, Robert, and Michael McGuire. 2001. Big questions in public network management research. Journal of Public Administration Research and Theory 11:295 326.

.2003. Collaborative public management: New strategies for local governments. Washington, DC: Georgetown Univ. Press.

Aldrich, Howard', and Diane Herker. 1977. Boundary spanning roles and organization structure. The Academy of Management Review 2:217 30.

Alter, Catherine, and Jerald Hage. 1993. Organizations working together: Coordination in interorga nizational networks. Newbury Park, CA: Sage.

Andrew, Simon A. 2009. Regional integration through contracting networks: An empirical analysis of institutional collective action. Urban Affairs Review 44:378 402.

Beinhocker, Eric D. 2007. The origin of wealth. Boston, MA: Harvard Business School Press.

Bernard, H. Russell, Peter D. Killworth, and Lee Sailer. 1982. Informant accuracy in social network data V: An experimental attempt to predict actual communication from recall data. Social Science Research Review 11:30 66.

Berry, Frances S., Ralph S. Brower, Sang Ok Choi, Wendy Xinfang Goa, HeeSoun Jang, Myungjung Kwon, and Jessica Word. 2004. Three traditions of network research: What the public management research agenda can learn from other research communities. Public Administration Review 64:539 52 .

Bogason, Peter, and Juliet A. Musso. 2006. The democratic prospects of network governance. American Review of Public Administration 36:3 18. 
Börzel, Tanja A. 1998. Organizing Babylon On the difference conceptions of policy networks. Public Administration 76:253 73.

Brass, Daniel J., Joseph Galaskiewicz, Henrich R. Greve, and Wenpin Tsai. 2004. Taking stock of networks and organizations: A multilevel perspective. Academy of Management Journal 47:795 817.

Burk, William J., Christian E. G. Steglich, and Tom A. B. Snijders. 2007. Beyond dyadic interdependence: Actor oriented models for co evolving social networks and individual behaviors. International Journal of Behavioral Development 31:397 404.

Burt, Ronald S. 1992. Structural holes. Cambridge, MA: Harvard Univ. Press.

Chisholm, Rupert F. 1998. Developing network organizations: Learning from practice and theory. Reading, MA: Addison Wesley.

Dawes, Sharon S. 1996. Interagency information sharing: Expected benefits, manageable risks. Journal of Policy Analysis and Management 66:377 94.

Feiock, Richard C. 2004. Metropolitan governance: Conflict, competition, and cooperation. Washington, DC: Georgetown Univ. Press.

. 2007. Rational choice and regional governance. Journal of Urban Affairs 29:47 63.

Feiock, Richard C., and John Scholz, eds. 2009. Self organizing federalism: Collaborative mechanisms to mitigate institutional collective action. New York: Cambridge Univ. Press.

Ferrin, Donald L., Kurt T. Dirks, and Pri P. Shah. 2006. Direct and indirect effects of third party rela tionships on interpersonal trust. Journal of Applied Psychology 91:870 83.

Freeman, J. Leiper. 1965. The political process. New York: Random House.

Galaskiewicz, Joseph. 1985. Interorganizational relations. Annual Review of Sociology 11:281 304.

González, Marta C., Cesar A. Hidalgo, and Albert Laszlo Barabási. 2008. Understanding individual human mobility patterns. Nature 453:779 82 .

Granovetter, Mark. 1985. Economic action and social structure: The problem of embeddedness. American Journal of Sociology 91:481.

Hatmaker, Deneen M., and R. Karl Rethemeyer. 2008. Mobile trust: Enacted relationships, social capital in a state level policy network. International Public Management Journal 11:426 62.

Heclo, Hugh. 1977. A government of strangers: Executive politics in Washington. Washington, DC: Brookings Institute.

Heikkila, Tanya A., and Kimberley R. Isett. 2004. Modeling operational decision making in public or ganizations: An integration of two institutional theories. American Review of Public Administration 34:3 19.

Helly, John. 1998. New concepts of publication. Nature 393:107.

Hoch, Charles. 2000. Sheltering the homeless in the U.S: Social improvement and the continuum of care. Housing Studies 15:865 76.

Huang, Kun, and Keith G. Provan. 2007. Structural embeddedness and organizational social outcomes in a centrally governed mental health services network. Public Management Review 9:16989.

Imperial, Mark T. 2005. Using collaboration as a governance strategy. Administration \& Society 37:281 320 .

Isett, Kimberley R., and Alan R. Ellis. 2007. Explaining new relationships: Sector, network, and organizational impacts on the growth of linkages in multi sector service delivery networks. In National Public Management Research Conference, Tucson, AZ, October 2527.

Isett, Kimberley Roussin., and Keith G. Provan. 2005. The evolution of dyadic interorganizational relationships in a network of publicly funded nonprofit agencies. Journal of Public Administration Research and Theory 15:149 65.

Kettl, Donald F. 1996. Governing at the millennium. In Handbook of public administration, ed. J. L. Perry, 5 18. San Francisco, CA: Jossey Bass.

.2000. Public administration at the millennium: The state of the field. Journal of Public Administration Research and Theory 10:7 34.

2006. Is the worst yet to come? The ANNALS of the American Academy of Political and Social Science 604:273 87. 
Kickert, Walter J. M., Erik Hans Klijn, and Joop F. M. Koppenjan, eds. 1997. Managing complex networks: Strategies for the public sector. London, UK: Sage.

Klijn, Erik Hans, and Joop F. M. Koppenjan. 2000. Public management and policy networks. Public Management Review 2:135 58.

Klijn, Erik Hans, and Chris Skelcher. 2007. Democracy and governance networks: Compatible or not? Public Administration 85:587 608.

Knox, Hannah, Mike Savage, and Penny Harvey. 2006. Social networks and the study of relations: Networks as method, metaphor and form. Economy and Society 35:113 40.

Koppenjan, Joop F. M., and Erik Hans Klijn. 2004. Managing uncertainties in networks: A network approach to problem solving and decision making. New York: Routledge.

Lambright, Kristina T., Pamela A. Mischen, and Craig Laramee. 2010. Building trust in public and nonprofit networks: Personal, dyadic, and third party influences. American Review of Public Administration 40:64 82.

Laumann, Edward O., and David Knoke. 1987. The organizational state. Madison, WI: Univ. of Wisconsin Press.

Lubell, Mark, Mark Schneider, John Scholz, and Mihriye Mete. 2002. Watershed partnerships and the emergence of collective action institutions. American Journal of Political Science 46:48 63.

MacKenzie, Robert. 2008. From networks to hierarchies: The construction of a subcontracting regime in the Irish telecommunications industry. Organization Studies 29:867 86.

Mandell, Myrna P. 2001. The impact of network structures on community building efforts: The Los Angeles roundtable for children community studies. In Getting results through collaboration: Networks and network structures for public policy and management, ed. M. P. Mandell, 12953. Westport, CN: Quorum Books.

Marsden, Peter V. 1990. Network data and measurement. Annual Review of Sociology 16:435 63.

McCool, Daniel. 1989. Subgovernments and the impact of fragmentation and accommodations. Policy Studies Review 8:264 87.

. 1990. Subgovernments as determinants of political viability. Political Science Quarterly 105:269 93.

McGuire, Michael. 2006. Collaborative public management: Assessing what we know and how we know it. Public Administration Review 66:33 43.

Meier, Kenneth J. and Lawrence J. O’Toole. 2003. Public management and educational performance: The impact of managerial networking. Public Administration Review 63:689 99.

Milward, H. Brinton, and Keith Provan. 1998. Principles for controlling agents: The political economy of network structure. Journal of Public Administration Research and Theory 8:203 22.

Minoglou, Ioanna Pepelasis. 2002. Between informal networks and formal contracts: International investment in Greece during the 1920s. Business History 44:40 64.

Monge, Peter R., and Noshir S. Contractor. 2003. Theories of communication networks. New York: Oxford Univ. Press.

Moore, Mark H. 1995. Creating public value: Strategic management in government. Cambridge, MA: Harvard Univ. Press.

Moynihan, Donald P. 2005. Leveraging collaborative networks in infrequent emergency situations. Madison, WI: IBM Center for the Business of Government.

Moynihan, Donald P., Sergio Fernandez, Soonhee Kim, Kelly M. LeRoux, Suzanne J. Piotrowski, Bradley E. Wright, and Kaifeng Yang. 2010. Performance Regimes amidst Governance Complexity. Journal of Public Administration Research and Theory 21(Supp. 1):i141 i55.

Mulroy, Elizabeth A., and Sharon Shay. 1998. Motivation and reward in nonprofit interorganizational collaboration in low income neighborhoods. Administration in Social Work 22:1 17.

Nelson, Lisa. 2001. Environmental networks: Relying on process or outcome for motivation. In Getting results through collaboration: Networks and network structures for public policy and management, ed. M. P. Mandell, 89 102. Westport, CN: Quorum Books.

O'Toole, Laurence J. 1997a. The implications for democracy in a networked bureaucratic World. Journal of Public Administration Research and Theory 7:443 59. 
. 1997b. Treating networks seriously: Practical and research based agendas in public adminis tration. Public Administration Review 57:45 52.

O’Toole, Laurence J., and Kenneth J. Meier. 2004. Desperately seeking Selznick: Cooptation and the dark side of public management in networks. Public Administration Review 64:681 93.

Osborne, David, and Ted Gaebler. 1992. Reinventing government: How the entrepreneurial spirit is transforming the public sector. Reading, MA: Plume.

Ostrom, Elinor. 1990. Governing the commons: The evolution of institutions for collective action. Cambridge, UK: Cambridge Univ. Press.

Powell, Walter W. 1990. Neither market nor hierarchy: Network forms of organization. In Research in organizational behavior, ed. B. Staw and L. L. Cummings, 295 336. Greenwich, CT: JAI.

Provan, Keith G., Amy Fish, and Joerg Sydow. 2007. Interorganizational networks at the network level: A review of the empirical literature on whole networks. Journal of Management 33:479 516

Provan, Keith G., and Patrick Kenis. 2008. Modes of Network Governance: Structure, Management, and Effectiveness. Journal of Public Administration Research and Theory 18:229 52.

Provan, Keith G., and H. Brinton Milward. 1995. A Preliminary theory of interorganizational network effectiveness: A comparative study of four community mental health systems. Administrative Science Quarterly 40:1 33.

. 2001. Do networks really work? A framework for evaluating public sector organizational net works. Public Administration Review 61:414 23.

Provan, Keith G., H. Brinton Milward, and Kimberley Roussin Isett. 2002. Collaboration and integration of community based health and human services in a nonprofit managed. Health Care Management Review 27:21 32.

Rethemeyer, R. Karl, and Deneen M. Hatmaker. 2008. Network management reconsidered: An inquiry into management of network structures in public sector service provision. Journal of Public Administration Research and Theory 18:617 46.

Rhodes, Roderick A. W. 1997. Understanding governance: Policy networks, governance, reflexivity and accountability. Buckingham, UK: Open Univ. Press.

Rittel, Horst W. J., and Melvin Webber. 1973. Dilemmas in a general theory of planning. Policy Sciences 4:155 69.

Rogers, David L., and David A. Whetten, eds. 1982. Interorganizational coordination: Theory, research, and implementation. Ames, IA: Iowa State Univ. Press.

Romzek, Barbara. 2008. The tangled web of accountability in contracting networks: The case of welfare reform. In Kettering Foundation Symposium on Accountability, Dayton, OH, May 2223.

Romzek, Barbara, and Jocelyn M. Johnston. 2002. Effective contract implementation and management: A preliminary model. Journal of Public Administration Research and Theory 12:423 53.

. 1999. Reforming medicaid through contracting: The nexus of implementation and organizational culture. Journal of Public Administration Research and Theory 1:107 39.

Salamon, Lester M. 1981. Rethinking public management: Third party government and the changing forms of government action. Public Policy 29:255 75.

. 2002. The tools of government: A guide to the new governance. New York, NY: Oxford Univ. Press.

Shrestha, Manoj, and Richard Feiock. 2004. Do cities cooperate in local public goods supply? A Transaction Cost and Social Exchange Explanation. Association for Public Policy Analysis and Management Annual Meeting, Atlanta, GA, October 2830.

Snijders, Tom A. B., and Roel Bosker. 2000. Multilevel analysis: An introduction to basic and advanced multilevel modeling. Thousand Oaks, CA: Sage.

Sørensen, Eva, and Jacob Torfing. 2005. Network governance and post liberal democracy. Administrative Theory \& Praxis 27:197 237.

Thacher, David. 2004. Interorganizational partnerships as inchoate hierarchies: A case study of the community security initiative. Administration \& Society 36:91 127.

Thurmaier, Kurt, and Curtis Wood. 2002. Interlocal agreements as social networks: Picket fence regionalism in metropolitan Kansas City. Public Administration Review 62:585 98. 
Wellman, Barry. 1983. Network analysis: Some basic principles. Sociological Theory 1:155 200.

Williamson, Oliver E. 1981. The economics of organization: The transaction cost approach. American Journal of Sociology 87:548 77. 